\title{
Charter Cities: Development Model or Neocolonialism?
}

\author{
Tillman van de Sand ${ }^{1 *}$ \\ ${ }^{1}$ Department of Economic Theory, Faculty of Economics, Andrássy University Budapest, \\ H-1088 Budapest, Pollack Mihály tér 3, Hungary \\ * Corresponding author, e-mail: till.v.d.sand@andrassyuni.hu
}

Received: 28 August 2018, Accepted: 15 January 2019, Published online: 07 August 2019

\begin{abstract}
Facing the problems of corruption, inefficient bureaucracy, a lack of property rights or of the rule of law in developing countries, Paul Romer, the current Chief Economist of the World Bank, has chosen a radical approach when he provided advice to the Honduran government in 2010. His idea was to establish a new constitution of the regional administrations and the legal framework in areas of developing countries where no settlements exist. To establish such a special administrative region, so called Charter City, a developing country requires a partner country which already enjoys credibility in terms of a functional administrative order. A high level of trust is presupposed, because the Charter City will be highly independent from the state ruling government. In fact Romer assumes that it is far easier to establish a new framework under the condition of good governance in a region which will attract citizens and investors than to change an existing system. Certainly the possibilities of a far-reaching independence contain some fundamental problems at the same time. The cultural heritage of a society and the country-specific characteristics might oppose the new order. Even when no one should be forced to live in a Charter City such problems will occur, because not only the region will change but also the rest of the country will be affected in the long term. In this context the activities of a partner country could be seen as an act of paternalism. The paper deals with the theoretical background of trust and compatibility in international administrative cooperation such as Charter Cities.
\end{abstract}

Keywords

Charter City, special administrative region, trust, international cooperation

\section{Introduction}

The increasing world population will confront us with serious challenges in a connected world. Since 2008, for the first time in human history, more than half of the world's population is living in cities. The process of urbanization mainly happens in emerging and developing countries (Population Reference Bureau, 2007). Especially those countries suffer from pauperism, bad infrastructure, political instability or military conflicts. Although military conflicts were responsible for a huge number of refugees in the last few years, the migration pressure caused by economic reasons rises, too. Since most of the causes of flight need to be combated within the countries of origin, it is inevitable to improve the local life conditions. This paper discusses whether and how the development of an independent administration, offered by a foreign nation, could be a suitable approach to guarantee political and legal stability in order to improve living conditions and reduce international poverty migration.

The on-going political debates about populism and nationalism reveal the importance of social and economic stability. The migration crisis puts the European Union to the test. In this context, however, it is obvious that of course not just financial and cultural cleavages occur in the European Union. Certainly, it is a catastrophe for the origin countries in the first place. The German economist, Michael Voigtländer (2016), argues that losing a generation of young, productive and communicative citizens tears an entire nation. The problem admittedly is not unknown, but the proposed solutions are very different and part of a controversial debate. A radical approach was formulated by the current Chief Economist and Senior Vice President of the World Bank, Paul Romer. He calls his concept Charter Cities. These are special administration zones within the territory of emerging and developing countries. These zones are characterized by a high independence from the local government. Foreign Countries provide the administration to credibly implement elements of good governance, which the United Nations define as: 
"Good governance has eight major characteristics. It is participatory, consensus oriented, accountable, transparent, responsive, effective and efficient, equitable and inclusive and follows the rule of law."

(UNESCAP, 2009: p. 1)

Romer alludes to the remarkable up growth of Hong Kong. When the People's Republic of China was proclaimed in 1949 Hong Kong, during that time a crown colony of the British Empire, became a haven for millions of people and countless companies. In contrast to the communistic China, in Hong Kong market-based economy was established under the rule of British law. In 1997 Hong Kong was assigned to China as one of the most powerful economic regions in Asia. China followed the example given by Hong Kong and founded itself 15 special economic zones in the mid-1980s. For that reason the US-American publicist George Gilder (2015) emphasizes that China did not take over Hong Kong but Hong Kong altered China. Of course the British rule was associated with military power and force. Romer, however, considers a voluntary relinquishment of national sovereignty to be possible, too. As an effect of a voluntary relinquishment of national sovereignty a Charter City would enjoy legitimacy. In Romer's point of view it would resist against every criticism calling this neocolonialism.

In the following section the leak of trust within administrations and societies will be discussed. For this purpose it is indispensable to distinguish between formal and informal institutions and interpersonal and generalized trust. This section is not a central issue of this paper, but it is important to understand where the idea of Charter Cities intervenes. In the third section the focus is on the concept of Charter Cities in particular. The paper will identify the main components on which a Charter City might be built on. Therefore, it is worth to outline Romer's concept which he elaborated in cooperation with the Honduran government in the early 2010s. Fourthly a review of the concept of Charter Cities against the background of institutions and trust will be presented. Moreover, the paper discusses the basis of legitimacy and the possible side effects of this project.

\section{Institutions and Trust}

If someone does not want to prejudge the idea of Charter Cities as a neocolonialist one, he or she has to understand the problems of bad governance in political systems and administrations. To prevent misunderstandings it is helpful to introduce Douglas North's famous definition of institutions at this point:
"Institutions are the humanly devised constraints that structure political, economic and social interaction. They consist of both informal constraints [...], and formal rules [...]. Throughout history, institutions have been devised by human beings to create order and reduce uncertainty in exchange." (North, 1991: p. 97)

On the contrary, organizations are actors, who interrelate with institutions. In particular, formal rules are controllable by different organizations. Depending from the existing political system, governments and parliaments as well as the people or non-democratic rulers are able to alter a country's laws or the constitution. Fundamental problems occur if these rules are not effective or modified in a bad way. This is called bad governance if one or more of the eight criteria of good governance have been contravened. In some cases this can explain huge differences in the living standard between two areas with same natural and cultural preconditions. The most obvious example is the gap between North and South Korea. Of course the North Korean regime is too powerful and is not interested in changing the status quo. On the other hand it is also possible that a government is too weak to improve the framework. In this case it is worth mentioning the example of Haiti. While Haiti's neighbor state, the Dominican Republic, became a vacation paradise, Haiti is still struggling with basic needs such as running water or electric supply (Allmeling, 2013). This suggests that the functionality of a system depends on its resistance against elite interests, because these lead to an inner inertness.

However, in reality often formal institutions are not crucial. Although it is possible to modify formal rules without any problems if the responsible persons are willing to do so, this does not mean that it is followed by the desired outcome in any case. Informal constraints and values such as customs and traditions are entrenched much more deeply in a society. In general, these kinds of institutions are inflexible in the short run. Solely shocking experiences are able to influence them in the short run. In addition to that, the Dutch cultural scientist Geert Hofstede et al. (2010: p. 20) developed a so-called Onion Model. The Onion's core consists of social values. The second level compromises rituals, while the third implies heroes. The forth and outer level includes all kinds of symbols. Rituals, heroes and symbols are a form of practices that are performed daily. The further away from the core a level is located, the quicker the content can be changed. Cultural values shape during childhood and it is very difficult to 
shift them. Hofstede therefore equates the national system of values with "given facts".

At this point it is important to expand the Onion Model by adding the dimension of trust. The German Economist Martin Raiser (1999: p. 4) distinguishes between three bonds of trust. The first group includes trust, which is generated through family relations. He calls it "ascribed trust". The second category, named "process-based trust", bases on friendships and acquaintanceships. Referring to Barbara Bernstein et al. (2006: p. 11), it seems reasonable to unite both groups to a single one, called "interpersonal trust". The third group is separated. "Extended trust" (Raiser, 1999: p. 4) or generalized trust occurs with anonymous interactions. Whereas interpersonal trust often roots in experiences, generalized trust is placed in advance and is independent form social relations. By transferring this to the economic system an inherent problem is noticeable. While in village communities the interpersonal trust plays a key role, the globalized world is characterized by generalized trust. The division of labor and the international trade happen at anonymous markets. This demands generalized trust in the society or in organizations that control those processes. Trust in political organizations is a special form of generalized trust. This is called political trust. The Canadian political scientist David Easton (1975: p. 437) focused his research on political structures and their legitimacy. He puts forward the thesis that two components are responsible for the stability of a political system. On the one hand it is the so-called "specific support" which refers to the political outcome. In other words citizens support a government because of its specific results. Of course the specific trust depending on economic circumstances and other impacts can be highly volatile. On the other hand there is the so-called "diffuse support". It bases on political trust and is deeply embedded in cultural values. In this case citizens support the political system in general because it matches their social values. Among other reasons, different forms of rule have emerged due to various social values. Easton figured out that it is exactly the diffuse support, which stabilizes a system in the long run.

Now it is important to focus on the problem of bad governance again. A high level of corruption and non-transparency destroys the political trust, while at the same time a lack of generalized trust leads to more interpersonal interactions that the shadow economy follows. The idea of exchanging political organizations from outside to break the vicious circle and to gain the people's generalized trust sets in at that point. It is very important to keep in mind that changing social values is not the aim of this process, but to benefit from social know-how. The rule of law is a basic condition to achieve this. Especially when it comes down to foreign investors who plan to make long term investments this aspect is crucial. Nevertheless, the close link of legitimacy, values and different types of trust is a complex one which must be taken into account in the further argumentation of this paper.

\section{Structure of a Charter City}

In the previous section, it was ascertained that creating a special administration zone, rather than reforming the existing system, may provide a solution to break the vicious circle of distrust and bad governance. In this context Brandon Fuller and Paul Romer (2012), the current Chief Economist of the World Bank, designed a radical approach with his idea of a Charter City. A Charter City is a special administration zone which is independent from its origin country's system to the greatest possible extent while offering a legal framework in terms of good governance.

The implementation of a Charter City bases on three different roles, states need to assume. The host country offers an area in its territory on which a Charter City will be constructed. In general, the host country is characterized as a developing country. The same applies to the source country. Citizens, who live and work in the Charter City, mainly originate from this country. The third role is taken over by a developed country which offers and implements a functioning administration and provides the legislation and jurisdiction. Consequently, having a functioning rule of law and a trustworthy administration in its own land is the most important requirement for handling this task. For that reason, this role is described as the guarantor country. Although one country could take on all roles at the same time, it is more likely that there are overlaps between the host and source country. Additionally, it does not necessarily have to be a single guarantor country, since cooperation with several guarantor countries is also conceivable.

Besides these three roles, the Charter City concept is based on four pillars that can be considered as requirements. As its name suggests, the first requirement is the charter itself. The charter constitutes the general structure of the Charter City as well as the cooperation agreement between the host and the guarantor country. In other words, this pillar deals with the constitutional law. It determines the primary law in which the Charter City is embedded. While the primary law symbolizes the first pillar, the secondary law represents the second pillar. The third pillar is all about fundamental freedoms such 
as free movement of goods, services, capital and persons. The fourth pillar contains some requirements on the territory of the Charter City. First of all, it is essential that the Charter City is located in an uninhabited area. After all, the legitimacy that stabilizes the Charter City results from a voluntary acceptance by the citizens. No one must be forced to accept the new constitutional order. Instead of that, people who move to the Charter City actively decide to live under those circumstances. Romer builds his argumentation on the ability of free choice. In his opinion, the legitimacy consists of the process of voting by feet. The free movement of persons has a key role to play in this matter. On account of this, an entire state or a disproportionately large region is not suitable for the implementation of a Charter City. In order to ensure that a Charter City can develop to a metropolis, it must also be constructed in a convenient location. This includes the consideration of location advantages. Ideally, it is located in a coastal area to provide a logistical connection to the world market by using an international harbor. To effect a positive development, a Charter City needs to encompass a proper size. National and international investors need to be attracted by the legal framework, but they also have to encounter a sufficiently large area. Besides a modern infrastructure, companies benefit from synergy effects and economies of scale. For this reason too, it is important to provide settlement areas for the workers and their families, as well as for universities or other major organizations. Another desirable factor is to reach enough people to achieve a significant improvement. It would be a laborious and ineffective process at village level. This argument is also related to the degree of trust within a society. In villages or smaller cities trust takes place on a personal level, while in bigger cities it is more about generalized trust. This is an important principle of the individualized capitalist system, where anonymous parties enter into contracts without knowing each other. However, a Charter City should not exceed a certain magnitude. In addition to the argument of legitimacy, a very big Charter City would be confronted with other problems such as a lack of transparency or incalculable risk. Because of this, a metropolitan region combines economic advantages with social responsibility.

In the case of Honduras, where a Charter City was almost established, concrete state structure has already been worked out. At the center of the Charter City was a Transparency Commission, which consisted of nine members and was supposed to make the essential political decisions. This transparency commission was supposed to represent the partner countries and would therefore not have been democratically elected by the inhabitants of Charter City. There should have been a legislative council subordinate to it, which would have regulated the secondary law. Furthermore, a Governor would have been appointed by the Transparency Commission to lead the administration. An audit committee would have collected statistics in order to evaluate the different state elements and to create transparency. The Charter City's Courts would also have been subject to external appeals courts.

\section{Critical Reviews on the Concept of Charter Cities}

So far, this paper illustrates several problems of bad governance and specifies the conditions under which a Charter City can be constructed. However, the implementation of a Charter City faces other challenges and difficulties, too. One of the most controversial aspects is the loss of control by the national authorities. A democratic participation is very limited not only during the process of formation. The Honduran constitutional court has already construed it as a contravention of state sovereignty when Romer and other experts wanted to implement the concept in Honduras in the early 2010s. In fact, the citizens would not be able to control the Charter City's new and independent leadership or to shape its political direction. The principle of equality with the rest of the country would at least be partially broken (Bird, 2012). At the same time, such a radical approach may be seen as a kind of paternalism (Himmelreich, 2010). In general, the idea seems to touch on a Eurocentric perspective. Thinking that crises in less developed countries could be resolved by adhering to Western ideas is very naive, negligent and in a way arrogant. History has apparently shown us that this cannot be very successful either.

Using Hong Kong as an example might be tempting, but de facto this is only a rare exception. Rather, history has taught us that the export of political systems and administrations is essentially accompanied by major conflicts. Furthermore the successful development of Hong Kong must been seen in a broader perspective. Looking back at the enormous rise of Hong Kong, it must be considered, that in the background of all there was a main conflict evoked by the two systems during the Cold War. The preconditions for globalization were fundamentally different from today. Although institutional interrelations and bad governance matter today in large areas of Africa and Latin America as they mattered in Hong Kong 40 years ago, it is negligent to assume that the effects of Charter Cities can be seen in the light of Hong Kong's history. Several decades of development aid and development cooperation 
also told us that the effort of implementing good governance brings up new conflicts. A code of conduct can certainly be prescribed, but it is far more difficult to influence social values. A Charter City is therefore confronted with uncontrollable peculiarities rooted in informal institutions. Geert Hofstede comments on this as follows:

"A country's values are strongly related to the structure and functioning of its institutions [...]. An important consequence of this fact is, that we cannot change the way people in a country think, feel and act by simply importing foreign institutions." (Hofstede et al., 2010: p. 24)

He continues his reservations and doubts and disputes that there is something like a universal path of development that can be demonstrated by developed countries:

"The rest of the world is not going Western [...]. Elections are not a universal solution to political problems. [...] Free market capitalism cannot be universal; it presumes an individualist mentality that is missing in most of the world. [...] Countries became more individualist after they increased in wealth, not wealthier by becoming more individualist. Free market capitalism suits countries already wealthy and is unlikely to turn poor countries into wealthy ones."

(Hofstede et al., 2010: p. 414)

A contradiction can be noticed. On the one hand, the cultural background of two different countries working together in a Charter City might be too great. It is not possible to simply adopt a functioning process from one country to another without focusing on the cultural peculiarities that are in some way connected to the problems that make this involvement necessary. This means that a Charter City needs to exclude certain characteristics of the source country's cultural imprint. Excluding these characteristics is only possible by not permitting a democratic order. This leads on the other hand to a democratic guarantor country acting in an undemocratic manner. Here, too, we must ask ourselves what characteristics the partner countries should bring with them. Even if the partnership is to be built on the principles of good governance, these criteria will reach their limits owing to the way in which they would be implemented. Due to contradictory behavior the guarantor country loses some of its credibility. The risk of paternalism resonates. People living in Charter Cities would not be able to take part in the politics, but only be able to consume the political outcome. This leads us to believe that these people are no citizens who have a say in policies, but that they are merely inhabitants. It is therefore questionable whether it is possible to bridge the gap between the consideration of cultural circumstances and the necessary transformation. The fact that some vacancies in the new administration system will have to be filled by local people does not guarantee a strong link between the both sides. In other words it is unclear whether an external actor is only able to reinforce the specific support or to receive diffuse support, too. Especially in very poor and impoverished regions it can happen that people are attracted primarily by a better economic status, but not by political trust.

The difficulties concerning this issue do not just occur between developed countries and developing countries but even within the European Union. Struggles of transformation processes are for example still visible in the former communist countries of Eastern Europe even after more than 25 years. A relatively high level of corruption and a lack of generalized trust still exist in these societies today. The current political crisis in the European Union reveals the enormous conflicts regarding the different cultural imprints that can already occur within a family of states. This inner-European conflict clearly shows that even within a broadly integrated community of states, the transfer of competences can lead to existential conflicts even under the priority of good governance. An existential lack of mutual understanding can be observed on both sides. In recent years, the European Union has allowed itself to drift apart by teaching in the decision-making process without analyzing and taking into account the social values of the member states. Ignorant attempts at Westernization are therefore doomed to failure. If this is applied to development cooperation, it must be recognized that it came to its limits in the past because the models successfully applied in the developed West cannot be applied one-to-one to all states. Rather, individual solutions must be found that best address the challenges of individual states. Achieving this understanding of a partner country and then combining it with one's own knowledge of good governance is a very great challenge.

This, however, is followed by a major problem of international relations, which would also come to bear in the case of a Charter City. After all, the partner countries are also pursuing their own agendas. No one can ensure that conflicts of interest do not arise. Particularly when we consider that the social values that stand in the background are different. 
Furthermore, due to the lack of opportunities for political participation, economic freedom and the free movement of persons are the main prerequisites for founding a Charter City. What Romer overrates in this context is his argument of voting by feet. The idea that people can always decide freely whether they want to move to a Charter City is only applicable if their living conditions are ignored. Just because people are not forced by a government to accept the new circumstances or to move to the Charter City does not mean that they leave their homes by free choice. If people are already risking their lives by passing the dessert or crossing the sea, despair is inhuman. So even if people move to a Charter City for economic reasons, this does not always mean that it is an act of free choice. It is inappropriate to call this behavior a rational choice.

Moreover, the condition to build a Charter City on an unsettled land is difficult to fulfill. People have already populated almost every strip of the globe. Accordingly, you will usually come across sparsely populated areas belonging to a local minority, natives or peasants. Groups such as these would be threatened by forced displacement through state authority. Not only groups of residents may obstruct a Charter City, but also the powerful elite of the existing system will not agree to a voluntary abdication of power. The incidents of the Honduran project are strong evidence of this. The Honduran government tried to maintain its influence by negotiating with an international investment group, although Romer and other experts were expected to concretize the establishment on an independent Charter City in Honduras. This was caused by the old elite finding themselves in a predicament. If a Charter City was successfully implemented, the old elite would be exposed as superfluous. This dilemma has the effect that the former elite is either trying to sabotage the successful development of Charter City from the outset or to claim the achievement itself. The former elite is therefore confronted with a structural credibility problem. Concerning this matter, the lack of trust within a society becomes important again. However, there may also be a third group of disadvantaged people. It is highly doubtful whether the public at large will benefit from a Charter City. In consequence of an efficient bureaucracy and pro-business adjusted tax system, it is very likely that foreign companies will force local enterprises out of the market, while they take the leading position in the Charter City's service sector. Thus, the German economist Stephan Klasen assumes that the well-educated and highly skilled labor force in particular will benefit from foreign investment
(Seebens, 2010). This leads to a far-reaching brain drain in the host country. According to the idea of a Charter City, the agricultural sector will not be embedded in the metropolitan area. This sector as well as the manufacturing sector will only indirectly benefit from the new system, if at all. At the same time, the increased income generated by foreign investment will increase the purchasing power and demand for goods. The costs of living will rise, which will not be affordable by all citizens. There is a continuing danger of leaving behind other areas of the host country. The voting by feet argument acts as a filter in two ways. In addition to this economic separation, ideological separation can also divide the country into a market liberal western part and a traditionally domestic part.

Due to increasing prices, however, some industries could be positively affected by a trickle-down effect. This effect may also extend to the surroundings. In order to avoid that the local population suffers from structural handicaps, the legal framework needs to ensure that the population can take part in the development process. For example, it is possible to set an employment rate or a minimum wage in order to strengthen the local population's ability to participate in economic upturn. Whereas Klasen assumes a brain drain hitting the surrounding areas, other experts such as the American economist Matthew Kahn expect a positive spillover effect on the surroundings. Precisely because highly educated people will be attracted by the Charter City, more people aspire to higher education. In fact, competition on the labor market will lead to more investments in the education system and a higher level of education throughout the whole country (Seebens, 2010). Such spillover effects could also occur in other contexts. An advanced competition is normally followed by the pressure to be innovative and efficient. In order to achieve a truly profound level of legitimacy, it is therefore advisable to partially compensate the losers of the reform process from the gains made by the Charter City.

In addition to these practical consequences, a bridge back to the meaning of democracy and freedom will now be built. The German politician Günter Nooke puts into perspective the fear that a charter city restricts these fundamental rights by ruling beyond the people's heads when he points out that the majority of development aid is already attached to conditions (Reifeld, 2010). Development loans from the World Bank or the International Monetary Fund are basically linked to conditions that influence the recipient country's political system and push it towards a system of good governance. Furthermore, it is important to keep in mind that even in western democracies there are lots of 
undemocratic elements, such as national banks. Actually, administrative tasks and legal affairs in several countries have already been taken over by foreign partners. One example for such cooperation is the United Nations Interim Administration Mission in Kosovo (Pennekamp, 2010). Although a Charter City, as mentioned before, will be confronted with external resistances, one of the advantages a Charter City brings is that there are no internal resistances. Here again, trustworthiness is a key factor because it is always connected to the future. If the new established political system confirms the shown trust, it will be able to shape the new metropolitan region very freely. In times of a rapidly growing world population and a dramatic urbanization process in the Third World, it is essential to shape the structures of aspiring cities as long as possible. Accompanying this process from the very beginning is crucial to sustainability in the sense of good governance. Paul Romer and his colleague Brandon Fuller summarize it as follows:

"The question, therefore, is not whether billions of people will soon gather together in cities, but where and under what conditions." (Fuller and Romer, 2012: p. 3)

While an increase in demand due to the rising world population leads to a shortage on a normal goods market, the concept of good governance and social know-how is spreading more and more (Reifeld, 2010).

\section{Conclusion}

Some people may see the idea of Charter Cities as a neocolonialist concept without democratic participation. This paper points out, however, that the aim is not to export western values to developing countries against their will. It is rather a question of providing support to countries in achieving a functioning rule of law if they intend to do so. Due to an inherent lack of generalized trust and bad governance, an external actor may most likely break the vicious circle. The biggest challenges during the implementation process are informal constraints As soon as a foreign actor tries to manipulate the cultural imprint, there will be strong backlashes. Voluntary selection is therefore inevitable. Nevertheless, people do not break with informal institutions just by crossing a border. Values simply are not alterable in the short run. They already have to be compatible to an individualistic system. For this reason, Charter Cities are not a universal solution, but they can contribute stability in various regions, depending on their ability to establish generalized trust and receive diffuse support. Specific support through economic development based on the rule of law might not suffice in the long run. Although the Charter City cannot be organized in a democratic structure, the inhabitants have to be involved. Travel facilitation, employees' rights, and investments in the education system, the health care system and infrastructure projects are essential to compensate for the piecemeal cultural opening. Apart from this, the inhabitants must also play an increasingly important role in shaping the future of their Charter Cities over time. Of course they must also be integrated in the administrative work. But even if some locals hold important positions, the transition to self-reliance depends on more or less arbitrary decisions by the guarantor country and the Transparency Commission. And even if Romer seems to solve the problem of legitimacy with a double safeguard by applying the concept of voting by feet at the individual level, it is necessary to first of all find a country that would be willing and legally able to renounce its sovereignty at the national level.

Finally, from my point of view, the concept of Charter Cities does not seem to be a neocolonialist approach. Charter Cities bear on the rule of law and a twofold voluntary decision. It is indisputable that the rule of law is a basic condition to attract investors and companies in the globalized world. It seems reasonable to benefit from foreign administrations and international expertise. But apart from all the problems that may occur because of cultural differences, it is important to point out that a so-called voluntary decision does not always have to be a free decision. The argument of voting by feet does not guarantee the diffuse support that is important for a successful development in the long run and it may cause an economical and ideological separation in the host and source country. All in all, Romer's model is a rewarding idea, although it is very likely that several projects will fail, as the development in Honduras indicates. It is worth thinking about this concept as a part of a responsible solution for preventing the migration pressure caused by economic reasons. However, sustainable development is only conceivable if the developed countries also rethink their cooperation and trade relations in other areas. The aim of the partnership cannot be to break the social values of another country make it follow a predefined development path, but to understand these values and to find an individually adapted solution. Even though developed countries can provide a wide range of suggestions for improvement and can play a leading role in implementing the principles of good governance, there is often a lack of 
understanding of the social values on which a successful implementation is based.

However, tensions will naturally also arise due to the fact that the partner country pursues a certain interest, too. For example, the European Union has now ventured into security policy cooperation with African states as part of its own geo-strategy.

\section{References}

Allmeling, A. (2013) "Haiti und die Dominikanische Republik: Eine Insel - zwei Welten" (Haiti and the Dominican Republic: One Island - Two Worlds), Deutsche Welle, [online] Available at: http:// www.dw.com/de/haiti-und-die-dominikanische-republik-eine-insel-zwei-welten/a-16590118 [Accessed: 12 November 2017] (in German)

Bernstein, B., Bittner, M., Ehs, T., Hudler-Seitzberger, M., Stromberger, C. (2006) "Vertrauen in Institutionen als Voraussetzung für Wirtschaftsentwicklung?: Eine Analyse am Beispiel ausgewählter Staaten Südosteuropas" (Trust in institutions as a condition for economic development?: An analysis based on the example of selected countries in Southeastern Europe), SWS-Rundschau, 46(1), pp. 7-33. [online] Available at: http://www.sws-rundschau.at/archiv/ SWS_2006_1_beinstein_etal.pdf[Accessed: 14 November 2017] (in German)

Bird, A. (2012) "Privately Owned "Charter Cities" in Honduras: Entire Urban Areas Handed over to Corporations: From neo-liberalism to neo-colonialism", Global Research, Centre for Research on Globalization, [online] Available at: https://www.globalresearch. ca/privately-owned-charter-cities-in-honduras-entire-urban-areas-handed-over-to-corporations/5304672 [Accessed: 09 November 2017]

Easton, D. (1975) "A Re-assessment of the Concept of Political Support", British Journal of Political Science, 5(4), pp. 435-457. https://doi.org/10.1017/S0007123400008309

Fuller, B., Romer, P. (2012) "Success and the City: How charter cities could transform the developing world", Macdonald Laurier Institute, [online] Available at: https://www.macdonaldlaurier. ca/files/pdf/How-charter-cities-could-transform-the-developingworld-April-2012.pdf [Accessed: 27 February 2017]

Gilder, G. (2015) "The 21st Century Case for Gold: A New Information Theory of Money", American Principles Project, Washington DC, USA.

Himmelreich, L. (2010) "Entwicklungshilfe: US-Ökonom empfiehlt Deutschland als Kolonialmacht" (Development aid: US economist recommends Germany as colonial power), Spiegel-Online, [online] Available at: http://www.spiegel.de/wirtschaft/soziales/ entwicklungshilfe-us-oekonom-empfiehlt-deutschland-als-kolonialmacht-a-668449.html [Accessed: 14 November 2017] (in German)

Hofstede, G., Hofstede, G. J., Minkov, M. (2010) "Cultures and Organizations: Software of the Mind: Intercultural Cooperation and its Importance for Survival", 3rd ed., McGraw-Hill, New York, USA.
Although Romer's idea of Charter Cities is an interesting concept for a number of reasons, its pure form is unlikely to be implemented and would in any case have to distance itself clearly from arguments on modernization theory. Therefore, the theory of Charter Cities can provide added value primarily through regional cooperation and must clearly distinguish itself from westernization.

North, D. C. (1991) "Institutions", Journal of Economic Perspectives, 5(1), pp. 97-112. https://doi.org/10.1257/jep.5.1.97

Pennekamp, J. (2010) "Entwicklungsökonomie: Der Stadtplaner als Welt-Retter" (Development Economics: The Urban Planner as World Saviour), Handelsblatt, [online] Available at: http:// www.handelsblatt.com/politik/konjunktur/oekonomie/nachrichten/entwicklungsoekonomie-der-stadtplaner-als-welt-retter-seite-2/3434790-2.html [Accessed: 09 November 2017] (in German)

Population Reference Bureau (2007) "World Population Highlights: Key Findings From PRB's 2007 World Population Data Sheet", Population Bulletin, 62(3), [online] Available at: https://motherchildnutrition.org/resources/pdf/mcn-prb-2007-highlights.pdf [Accessed: 14 January 2018]

Raiser, M. (1999) "Trust in Transition", European Bank for Reconstruction and Development, London, UK, Working Paper No. 39.

Reifeld, H. (2010) "Paul Romer erklärt sein Konzept der Charter Cities" (Paul Romer explains his concept of charter cities ), Im Plenum Kompakt: Entwicklungspolitik Kontrovers, Konrad Adenauer Foundation, May, pp. 1-6. [online] Available at: https://www.kas. de/c/document_library/get_file?uuid=8d6379f5-de58-0c8b-75d2bf70bea39bad\&groupId=252038 [Accessed: 14 January 2019] (in German)

Seebens, H. (2010) "Charter Cities: eine Alternative zur EZ?" (Charter Cities: an alternative to development cooperation), Kreditanstalt für Wiederaufbau, Entwicklungspolitik Kompakt, July, [online] Available at: https://www.kfw-entwicklungsbank.de/DownloadCenter/PDF-Dokumente-Development-Research/2010_07_EK_ Seebens-Charter-Cities_D.pdf [Accessed: 14 January 2019] (in German)

UNESCAP (2009) "What is Good Governance?", United Nations Economic and Social Commission for Asia and the Pacific, United Nations, [pdf] Available at: https://www.unescap.org/sites/default/ files/good-governance.pdf [Accessed: 14 January 2019]

Voigtländer, M. (2016) "Charter Cities: Ein alternativer Ansatz der Flüchtlingspolitik" (Charter Cities: An alternative approach to refugee policy), Institute for deutschen Wirtschaft, [online] Available at: https://www.iwkoeln.de/presse/gastbeitraege/ beitrag/michael-voigtlaender-auf-oekonomenstimme-charter-cities-ein-alternativer-ansatz-der-fluechtlingspolitik-295333 [Accessed: 02 November 2017] (in German) 